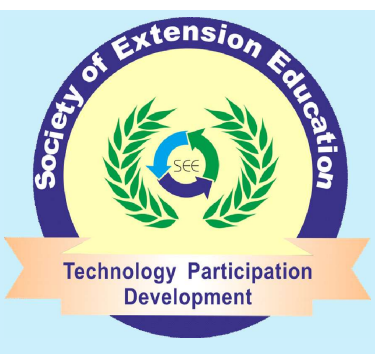

Research Note

\section{Indian Research Journal of Extension Education}

ISSN: 0972-2181 (Print), 0976-1071 (Online)

NAAS Rating : 5.22

Journal homepage: seea.org.in

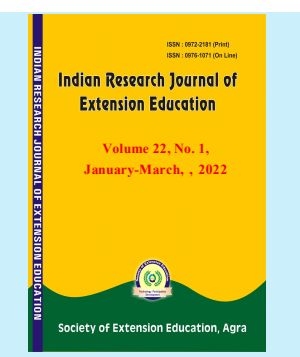

https://doi.org/10.54986/irjee/2022/jan_mar/142-145

\title{
Development of Cognitive Learning Scale to Test the Knowledge Level of Veterinary Students on ICT
}

\author{
Subhransu Mohan Nanda ${ }^{1}$, Arunasis Goswami ${ }^{2}$ and Sukanta Biswas ${ }^{3}$ \\ 1.Ph.D. Scholar, 2. Prof., 3. Asso. Prof., Vet. \& AH Ext. Edu., WBUAFS, Kolkata, India \\ Corresponding author e-mail : vetsubhransu14193@gmail.com \\ Paper Received on August, 13, 2021, Accepted on Novembe 20, 2021 and Published Online on January 01, 2022
}

\begin{abstract}
In the present study, to test the knowledge level of veterinary students on ICT, one hundred and seventy-one items were initially constructed on the basis of promoting thinking rather than rote memorization. It was designed in a manner that could differentiate the well-informed veterinary students from less informed ones. The scores of the respondents were subjects to item analysis to find the item difficulty index and item discrimination index. In the final selection, a total of 34 items with difficulty index between 30 and 80 and discrimination index ranging from 0.30 to 0.55 were selected. The reliability of the knowledge test developed was tested using split half technique. The coefficient of correlation value in split half test was 0.89, which was found to be significant at 1 per cent level of significance. It was found that, the developed knowledge test scale of Veterinary students on ICT was highly stable and can be used for measurement.
\end{abstract}

Key woreds : ICT; Knowledge; Learning scale; Veterinary students.

The Information and Communication Technologies (ICT) is an extension term for Information Technology that emphasizes on the role of unified communications and the integration of telecommunications and computers (Murray and James, 2011). The knowledge of ICT is currently essential for every higher academic student. Time is not far when each and every graduate will be forced to learn coding to sustain in this technological era. It was found from a study conducted on veterinary students of India that techniques of e-learning were mostly useful for the students from less affected families with sound income (Das et al, 2021). A standardized scale to measure ICT operational self-confidence of the farmers while using the ICT tools and services was developed by Tandodara and Chauhan, 2021. In order to assess the knowledge level of the people regarding method of preparation of traditional dairy products, a knowledge test was developed where 11 statements were selected for the final evaluation of the respondents (Chatterjee et al. 2020). A total of 22 statements were framed in which finally 10 statements were finally retained which has practical applicability in measuring the attitude of postgraduate scholars towards extension education (Naveenkumar and Chauhan, 2020). This study aims at developing a scale to measure the knowledge level of veterinary students on ICT.

\section{METHODOLOGY}

This research study reports the construction of a cognitive learning scale to test the knowledge level of veterinary students on information communication and technology. 
Collection of items : The items refer to the questions present in the knowledge, which forms the content of the test. The items were collected from different sources like- literature, subject matter specialists, digital resources and researcher's own experience.

Initial selection of items : The items were selection on the basis of the criteria that, they should promote thinking rather than memorization and they should be able to differentiate the well-informed veterinary students from less informed ones. The questions were designed in dichotomous scale. The procedure followed was in the line of the learning scale developed by Goswami et al, 2011 on knowledge level of duck farmers.

\section{RESULTS AND DISCUSSION}

Preliminary administration of Test : Items were administered to 60 veterinary students of College of Veterinary Science and Animal Husbandry, OUAT, Bhubaneswar, Odisha, a state of India. Each respondent was given score 1 or 0 for each correct and wrong answer respectively. The total number of correct answers given by a respondent was the score of a total of 171. After calculating the scores obtained from 60 veterinary students, the scores were arranged in descending order. The 60 respondents were divided into 6 groups $\left(G_{1} \ldots G_{6}\right)$ with 10 members each. The respondents were arranged in descending order according to the total score obtained by each one of them. The extreme four groups with high and low scores were selected for computation of item difficulty index and item discrimination index.

Item analysis : Item analysis of a test provides two types of information-item difficulty index which speaks about the difficulty level of an item and item discrimination index which indicates how well the item discriminates in agreement with the test of the scale. (Guliford, 1954).

Item difficulty index: The difficulty index of an item was defined as the proportions of veterinary students giving correct answers to that particular item. This was calculated using the formula:

Where,

$$
P_{i}=\frac{n_{i}}{N_{i}} \times 100
$$

$\mathrm{P}_{\mathrm{i}}=$ Difficulty index in percentage of ith item

$\mathrm{n}_{\mathrm{i}}=$ Number of veterinary students giving correct answer to the ith item
$\mathrm{N}_{\mathrm{i}}=$ Total number of veterinary students to whom ith item was administered (60 in this research)

While computing item difficulty index, all the respondents were taken into consideration.

Item discrimination index: The discrimination index may be defined as the measure of capability of the item to differentiate the well informed respondents and the less informed respondents. The following formula was used for calculation of this index.

$$
\mathrm{E}^{1 / 3}=\frac{\left(\mathrm{S}_{1}+\mathrm{S}_{2}\right)-\left(\mathrm{S}_{5}+\mathrm{S}_{6}\right)}{\mathrm{N} / 3}
$$

Where,

$\mathrm{S}_{1}, \mathrm{~S}_{2}, \mathrm{~S}_{5}$ and $\mathrm{S}_{6}$ were the frequencies of correct answers in $\mathrm{G}_{1}$, $\mathrm{G}_{2}, \mathrm{G}_{5}$ and $\mathrm{G}_{6}$ groups respectively and $\mathrm{N}=$ Total number of veterinary students in the sample of the item analysis

Selection of items for the test : The final format of knowledge test was prepared after considering the values of item difficulty and item discrimination indices. In the present study, the items with item difficulty index ranging from 30 to 80 and discrimination index ranging from $0.30-0.55$ were selected to be included in the final list of knowledge test. The number of total selected items was 34 (Table 1).

Scoring method: The summing up of scores for correct replies over all the items of a particular respondent indicates his/her knowledge about ICT. The range of scores was from 0 to 34 .

Reliability by Split half technique : All the 34 items were arranged randomly and divided into two equal halves of 17 items each. The two sets were administered to 30 veterinary students of Faculty of Veterinary and Animal Sciences, West Bengal University of Animal and Fishery Sciences, Kolkata, India. The coefficient of correlation $(r)$ between two sets of scores was found out to be 0.89 , which was significant at $1 \%$ level of significance. The reliability coefficient thus obtained, indicated the "internal consistency" of the knowledge test developed for this study was high.

Content validity of the knowledge test : Proper care was taken to include items from the entire universe relevant to behavioral aspects of the respondents with respect to knowledge about ICT. The items were collected from different relevant literature, specialists and various other sources. Thus, it was assumed that the measurement was done as intended. 


\section{Table 1. Item difficulty and item discrimination} index values of the selected items

\begin{tabular}{|c|c|c|}
\hline Items & IDI & IDiI \\
\hline ICT includes only usage of computer. & 71.81 & 0.35 \\
\hline DDR3 is a type of RAM used in computer & 70.14 & 0.35 \\
\hline Name any one national internet service provider & 53.44 & 0.45 \\
\hline Can you work using R? & 30.06 & 0.35 \\
\hline Can you change your background in google meet? & 75.15 & 0.35 \\
\hline Can you blur your background in Google meet? & 63.46 & 0.35 \\
\hline Does google play store provide all free Application? & 70.14 & 0.35 \\
\hline Will app store work on android mobiles? & 33.4 & 0.5 \\
\hline Do you use ResearchGate? & 40.08 & 0.45 \\
\hline Are you aware of Google Scholar? & 45.09 & 0.3 \\
\hline Pen tablet is an output device & 38.41 & 0.45 \\
\hline $\begin{array}{l}\text { The milking robots equipped with sensors to } \\
\text { detect signs of mastitis which measures the } \\
\text { many characters of the abnormal milk }\end{array}$ & 73.48 & 0.55 \\
\hline $\begin{array}{l}\text { Sponsoring agency of cyber extension project } \\
\text { is MANAGE, Hyderabad. }\end{array}$ & 53.44 & 0.45 \\
\hline Computer based test is better than traditional exam. & 55.11 & 0.4 \\
\hline $\begin{array}{l}\text { USB tethering is an alternative method to } \\
\text { connect to internet via cell phones }\end{array}$ & 61.79 & 0.5 \\
\hline Mac Book contains IOS & 66.8 & 0.35 \\
\hline Winamp is an audio playing software & 53.44 & 0.35 \\
\hline LINUX is an operating system & 71.81 & 0.55 \\
\hline Adobe XD helps in wire framing & 43.42 & 0.45 \\
\hline Graph pad prism is used to plot graphs for res. works & 50.1 & 0.55 \\
\hline Name three different types of printers. & 33.4 & 0.55 \\
\hline What does UPS stand for? & 41.75 & 0.5 \\
\hline JPG, JPEG are the file extension names of audio files & 78.49 & 0.45 \\
\hline Mathtype is software to write mathematical equation & 60.12 & 0.55 \\
\hline Quickheal is a photo editing software & 73.48 & 0.55 \\
\hline $\begin{array}{l}\text { ICTs provide possible solutions of problems } \\
\text { related to animal husbandry }\end{array}$ & 78.49 & 0.5 \\
\hline $\begin{array}{l}\text { ICTs cannot meet location specific needs of } \\
\text { livestock owners }\end{array}$ & 51.77 & 0.45 \\
\hline $\begin{array}{l}\text { Farmers' feedback is fast through ICTs than } \\
\text { traditional tools }\end{array}$ & 73.48 & 0.5 \\
\hline $\begin{array}{l}\text { It is possible to get solution of personalized } \\
\text { problems through ICTs }\end{array}$ & 46.76 & 0.5 \\
\hline ICT application reduces the socio-cultural barriers & 66.8 & 0.5 \\
\hline $\begin{array}{l}\text { Though ICT is a valuable tool, but it will } \\
\text { never influence farmers' own decision making }\end{array}$ & 56.78 & 0.45 \\
\hline $\begin{array}{l}\text { Weather forecasting through ICTs assists } \\
\text { farmers in timely decisions }\end{array}$ & 78.49 & 0.5 \\
\hline $\begin{array}{l}\text { Phone-in-live with scientists gives first-hand } \\
\text { information about queries }\end{array}$ & 73.48 & 0.55 \\
\hline There are 101 keys in a standard keyboard & 76.82 & 0.4 \\
\hline
\end{tabular}

IDI=Item difficulty index, IDiI=Item discrimination index
Table 2. Scale to test the knowledge level of veterinary students about ICT

\begin{tabular}{lll}
\hline Items & C & I \\
\hline ICT includes only usage of computer. & 0 & 1 \\
DDR3 is a type of RAM used in computer & 1 & 0 \\
Name any one national internet service provider & 1 & 0 \\
Can you work using R? & 1 & 0 \\
Can you change your background in Google meet? & 1 & 0 \\
Can you blur your background in Google meet? & 1 & 0 \\
Does Google Playstore provide all free applications? & 0 & 1 \\
Will app store work on android mobiles? & 0 & 1 \\
Do you use ResearchGate? & 1 & 0 \\
Are you aware of Google Scholar? & 1 & 0 \\
Pen tablet is an output device & 0 & 1
\end{tabular}

The milking robots equipped with sensors to detect signs 10 of mastitis which measures many characters of abnormal milk

Sponsoring agency of Cyber Extension Project is $\quad 1 \quad 0$

MANAGE, Hyderabad.

Computer based test is better than traditional examination $1 \quad 0$

USB tethering is an alternative method to connect $\quad 10$

to internet via cell phones

MacBook contains iOS $\quad 1 \quad 0$

Winamp is an audio playing software $\quad 1 \quad 0$

$\begin{array}{lll}\text { LINUX is an operating system } & 1 & 0\end{array}$

Adobe XD helps in wire framing $\quad 1 \quad 0$

Graph pad prism is used to plot graphs for research $\quad 1 \quad 0$

Name three different types of printers. $\quad 1 \quad 0$

What does UPS stand for? 10

JPG, JPEG are the file extension names of audio files $\quad \begin{array}{lll}0 & 1\end{array}$

Mathtype is software to write mathematical equations $\quad 10$

$\begin{array}{lll}\text { Quickheal is a photo editing software } & 0 & 1\end{array}$

ICTs provide possible solutions of problems related $\quad 1 \quad 0$

to animal husbandry

ICTs cannot meet location specific needs of livestock owners $\quad \begin{array}{ll}0 & 1\end{array}$

Farmers' feedback is fast through ICTs than traditional tools $1 \quad 0$

It is possible to get solution of personalized problems $\quad 1 \quad 0$

through ICTs

ICT application reduces the socio-cultural barriers $\quad 1 \quad 0$

$\begin{array}{lll}\text { Though ICT is a valuable tool, but it will never } & 1 & 0\end{array}$

influence farmers' own decision making

Weather forecasting through ICTs assists farmers $\quad 1 \quad 0$

in timely decisions

Phone-in-live with scientists gives first-hand $\quad 1 \quad 0$

information about queries

There are 101 keys in a standard keyboard

10

$\mathrm{C}=$ Correct; $\mathrm{I}=$ Incorrect 


\section{CONCLUSION}

The knowledge test scale prepared through this research study can be used universally to identify the knowledge level of veterinary students on Information and Communication technology. This test can be employed to improve the weak areas on ICT of veterinary students across the globe to facilitate online learning during this COVID-19 pandemic period.

\section{CONFLICTS OF INTEREST}

The authors declare that they have no conflicts of interest.

\section{REFERENCES}

Chatterjee, D.; Jha, S.K. and Maiti, S. (2020). Development of knowledge test regarding method of preparation of traditional dairy products. Indian Research Journal of Extension Education, 20 (2\&3) : 17-21

Das, P. K.; Pandiyan, G.D.V.; Parkunan, T.; Ingole, S.D.; Patra, A.K., Ghosh, P.R. and Goswami, A. (2021). Impact of COVID19 pandemic on some academic aspects of veterinary students in India. The J. Agril. Edu. and Ext., DOI : 10.1080/ 1389224X.2021.1932536

Goswami, A.; Ghosh, R.K. and Maitra, N.J. (2011). Development of cognitive learning scale to test the knowledge of duck farmers about duck farming. Envir. and Ecol., 29 (3) :1114-1118.

Guilford J. P. 1954. Psychometric methods. McGraw Hill, New York, India

Murray, James (2011). Cloud network architecture and ICT - modern network architecture". TechTarget=IT Knowledge Exchange.

Naveenkumar, G. and Chauhan, N.B. (2020). Device to measure extension education orientation of postgraduate scholars. Indian Res. J. Ext. Edu., 20 (1) : 31-34

Tankodara, K.D. and Chauhan, N.B. (2021). Scale to measure ICT operational self-confidence of the farmers. Indian Res. J. Ext. Edu., 21(1) : 16-19 